\title{
The Relationship Between the Self and Others in Williams' Theory of Integrity
}

\author{
Yong Tan \\ School of Public Administration, Nanjing Normal University, Nanjing, China \\ Email address: \\ 838678030@qq.com \\ To cite this article: \\ Yong Tan. The Relationship Between the Self and Others in Williams' Theory of Integrity. International Journal of Philosophy. \\ Vol. 9, No. 1, 2021, pp. 66-71. doi: 10.11648/j.ijp.20210901.16
}

Received: March 8, 2021; Accepted: March 17, 2021; Published: March 26, 2021

\begin{abstract}
Williams puts forward and develops his theory of integrity on the basis of criticizing utilitarianism and Kantian ethics as too demanding to make enough room for personal projects. Instead, his integrity theory advocates that we should act out of commitments with which we deeply identify ourselves. In doing so, we express who we really are and make our life meaningful. If not so, our integrity would be violated and we may lose ourselves. Such a description of the self in moral life is criticized as solipsism for that it makes the relationship between one's projects and himself only be regulated by himself. This paper aims to point out that such criticism is inappropriate. To show the inaccuracy of the criticism, the author will analyze the relationship between the self and others in two aspects. The first aspect is about the structure of formation of desires and others, and the second one is about the action responsibility and others. After analysis, in the first aspect of desires, the self needs others to form and stabilize desires, beliefs and motivations to cooperate with others. Others help the self to sustain the sense of reality to prevent the self from forming wishful thinking. As to action, others' need for response is an important element in ascribing the self's action responsibility. The self acquires self-conception, self-cognition and self-identity through the interaction with others. Thus, others play an essential role in Williams' theory of integrity. Although there are some flaws in Williams' integrity theory, to reexamine his theory is conducive to our understanding of moral life.
\end{abstract}

Keywords: Williams, Integrity, Self, Authenticity, Action

\section{Introduction}

In ancient society, people embedded themselves into different kinds of relationships, including those with others, with groups in society, and with nature. In this way, self was one part of a whole structure. Thus, individuals, according to the appropriate positions that they were in, acquired self-identification, behavioral norms, sense of worth and the meaning of life.

Such understanding of the self has totally changed in modern era. People do not see themselves as one part of a whole structure. Instead, they see themselves independent and free, trying to break away from the order that some structures demand. Simultaneously, people put the importance of self-understanding to the inner self, thus authenticity is emphasized. Williams' theory of integrity is one representative of authenticity. According to his integrity theory, people should act and lead their life in accordance with their deepest desires, only through which way can their life be meaningful. Such a standpoint is criticized in many aspects, one of which is that this theory treats the self as a solipsist. Many scholars hold the same criticism and think that integrity is not that important. The self must be restricted by morality. Others supporting the idea that integrity is necessary to personal life think that the content of integrity is conditional. Their analysis shows the importance of such restrictions or conditions.

In this paper, by analyzing Williams' ideas, I will try to show that how a normally socialized person can realize such restrictions or conditions and avoid himself from becoming a solipsist. Firstly, I will try to clarify the content of integrity in section 2. Secondly, I will discuss Williams' analysis on desires in section 3. Thirdly, in section 4, I will expound Williams' view on action and its relationship with integrity, and the ascription of action responsibility. After discussion, I will point out that in Williams' integrity theory, others participate in forming and stabilizing one's desires, ascribing one's responsibility, and helping to construct one's 
self-cognition. Therefore, the self in Williams' integrity theory is not a solipsist. In the last section, I will give a short account of how to better understand Williams' integrity theory.

\section{Integrity and Authenticity}

Integrity is a complex concept in ethics, and different philosophers use it in different ways. Williams defines 'integrity' by using the terms he calls 'categorical desires' and 'ground projects'.

As to desires, "if one desires something, then to that extent one has reason to resist the happening of anything which prevents one getting it, and death certainly does that, for a large range of desires." [1] Obviously, many desires and their fulfillment depend on the reality that a person is alive. ${ }^{1}$ If someone decides to go on in life, he is propelled forward by some desires. Such desires settle the question of whether he is going to be alive. Williams calls such a desire a categorical desire. Categorical desires not only push someone forward and give him a reason to be interested in what happens within the horizon of his future, but also constitute the conditions of there being such a future at all. In a word, such a desire connects the present and the future. Categorical desires include many things, such as career goals, ideal characters, artistic pursuit, harmonious interpersonal relationships. And one may have many kinds of categorical desires.

Ground projects are long or short life planning, which are made according to one's categorical desires. Such projects give a person the meaning of life. As Williams explains, ground projects do not have to be selfish or self-centered, in the sense that they are just related to the agent. Ground projects may certainly be altruistic. Teresa devoted all her life to charity. Ground projects are closely related to one's existence, giving a meaning to his life. If one project is frustrated, he does not have to commit suicide or contemplate that. Other things or mere the hope of other things may keep him going. Only all or most of the projects are frustrated may he lose the meaning of life.

It's worth noting that categorical desires and ground projects, which constitute the inward content of integrity, ${ }^{2}$ should be acknowledged by a person himself, rather than be imposed on him by others. For example, Owen was born in a military family, being wished to join the army, and got training when he was a child. However, he becomes interested in arts and wants to take arts as his career. His family urge on him the necessity and importance of his joining the army for the family pride. Owen doesn't agree on all that reasons that his family urge on him. If he in the end is forced to join the army, the ground project is not acknowledged by himself. ${ }^{3}$ In this sense, it reveals the

\footnotetext{
1 Not all desires are contingent on the prospect of one's being alive. It is possible to imagine a person rationally contemplating suicide

2 Action constitutes the outward manifestation of integrity, contrary to the inward content, which I will discuss later.

3 This Owen example is based on Williams' article Internal and External Reasons.
}

essential feature of Williams' integrity, which can be attributed to internalism. Williams is an internalist. He thinks that all the reasons that motivate agents are connected with their subjective motivational set, ${ }^{4}$ which is the concept he uses to explain internal reasons. The contents of $S$ include many things, such as agents' desires, attitudes towards something, inclination, dispositions of evaluation, patterns of emotional reaction, personal loyalties and projects, "as they may be abstractly called, embodying commitments of the agent".[2] In Owen's example, his family express themselves by saying that there is a reason for Owen to join the army. Through deliberative reasoning, there is nothing in Owen's $S$ would lead to his doing so. The reasons would be external ones if the family cannot convince Owen. If Owen finally decides to join the army, it is because he truly believes the reason that he should continue his family's military tradition. External reasons can be true iff psychological link, which seems to be belief, comes in mind. An agent needs to find something in his $S$ to believe the external reasons.

It appears that Williams' argument presupposes that the relationship between one's life projects and himself can only be mediated by himself [3]. What's more, the categorical desires and ground projects are not necessarily of moral sense [4]. We will see that the main points in Williams' integrity theory are no different from the ethics of authenticity, which is a modern ethical ideal. According to Charles Taylor, the ethic of authenticity is an important issue in modern society. Herder, a major early articulator, puts forward the idea that each of us has an original way of being human [5]. Rousseau articulates the idea in a most influential way in his writings. In his eyes, the development of modern civilization is accompanied by instrumental role-playing. Thus, alienation from inner self is caused [6]. Rousseau calls on us to listen to the inner voice, rather than fit the self to the demands of external conformity. "There is a certain way of being human that is my way. I am called upon to live my life in this way, and not in imitation of anyone else's. But this gives a new importance to being true to myself." [5] Rousseau tries to solve the tension, which is a problem emerging from the emphasis on authenticity, between individuality and the demands of virtue. However, he somehow failed. After him, some later ideas offered authenticity in a more distinctive form, in which it represented an heroic ideal of coinciding with oneself and one's deepest needs or impulses, whatever they might be, to the exclusion of other demands [7]. We can see that Williams' integrity follows the internal route, and expresses the self in authentic way, in which we should follow our deepest impulses, listen to ourselves within, be true to ourselves and expresses ourselves sincerely, thus a true self is revealed.

As mentioned before, a problem, which is the incompatibility between individuality and the demands of morality, arises. Thus, Williams' integrity is criticized as solipsism [8]. However, such criticism is inappropriate. To

\footnotetext{
4 For convenience, I will use $S$, as Williams does, to replace all the following "subjective motivational set" phrases.
} 
show this, I will elucidate Williams' discussion on desires and action.

\section{The Structure of Formation of Desires and Others}

Sincerity plays an important role in Rousseau's idea of authenticity. His conception of authenticity requires the authority of self-discovery: the idea that sincere, spontaneous, non-deceitful declaration, the product of one's presence to oneself, will guarantee a true understanding of one's own motives. Moreover, what is revealed and understood in this way will represent a character and a whole person. However, would such sincere self-declaration, as Rousseau suspected in the end, really reveal the true self? Because it is possible that a person knows nothing about what he or she needs or wants. The spontaneity of assertion of oneself cannot be judged true or false on the content of that assertion. How to cope with such situation? Before getting to this point, I will first discuss the way, which Williams applies to deal with assertions of factual state of affairs. It is necessary because the formation of desires shares almost the same structure.

In the factual state of affairs aspect, the speaker spontaneously asserts something, and that assertion may be true for the assertion act itself. It is still possible that the speaker believes what he asserts, while actually he is wrong. Take a person believing in geocentric theory for example. Leaving aside such cases, "there are cases in which an assertion presents itself, but he has some reason to wonder whether it is true. Again, there are, very importantly, cases in which no definite assertion presents itself, but some proposition, a thought or content, does." [9] The speaker may reflect on other reasons that bear on the matter to decide whether he should believe it or not. While the reason why a person uses reflection is that he is having a trusting dialogue with another person who relies on him. According to Williams, assertions take place in the context of one person's telling something to another. If the speaker admits that he is wrong, and goes on saying the same thing to people who have shown him that he was wrong, then it may become unintelligible what he is up to. To better understand the idea of assertion, we need psychological notions such as belief and intention.

In the dialogue context, the speaker utters a sentence as an assertion to express his belief. "We might say that A asserts that $\mathrm{P}$ in uttering a sentence which means that $\mathrm{P}$, in doing which he expresses his belief that P." [10] However, it is not always the case. Pretending to express his belief, the speaker may lie. Why does he lie? In Williams' analysis, the speaker's fake assertion aims to misinform the hearer about his belief. In this case, he may know that the hearer will not believe what he falsely asserts while he intends to make the hearer believe that he himself believes it. Williams draws the conclusion as follows: A utters a sentence "S", where "S" means that $\mathrm{P}$, in doing which either he expresses his belief that $\mathrm{P}$, or he intends the person addressed to take it that he believes that $\mathrm{P}$ [11]. Williams takes it to be an adequate account of what assertion centrally is for that it explains the connection between the assertion and truth and provides a natural place for the expectation of sincerity.

The importance of sincerity becomes prominent in the following situation; Williams thinks that everyone is brought up in a world in which he or she shares needs with others, except in very desperate circumstances. "The basic mechanism depends on the fact that there are others who need to rely on our dispositions, and we want them to be able to rely on our dispositions because we, up to a point, want to rely on theirs." [12] We, however, may be unclear about what we believe. At this time, we need others' help because they have experience and knowledge that we don't have. We come to know what we believe with the help of others and thus obtain some factual beliefs. Similarly, others come to know what they believe and obtain some factual beliefs with the help of us. All of us are in such social activities of mutually stabilizing our declarations, moods and impulses into becoming such things as beliefs and relatively steady attitudes.

Back to the desire aspect, Williams thinks that the same structure can be also applied to help us construct our desires. He distinguishes desires from wishes or wishful thinking. As Williams points out, if our beliefs aim to be true, we have to take them to be independent of our will, contrary to sheer wishful thinking. That is to say, our beliefs are answerable to the world, which means they can response to the world. If a person wants the belief $P$ to be true just because it is his wish that $\mathrm{P}$, nothing else, then he forms the belief $\mathrm{P}$ on the basis of being divorced from reality. This is the case in which the belief $\mathrm{P}$ is served just to satisfy the person's wish. Analogously, if a person knows well that he cannot bring about or affect something in a practical sense, that something can only be reduced to his content of wishes. All things considered, Peter wants to fly freely in the sky like Superman does. However, according to Williams, this is just a wish. Of course, there is a sense in which some actual state of affairs are dependent on our will, which is to say that we can take control of some changes. All things considered, Peter wants to go wingsuit flying. According to Williams, this can be a desire. Wishes and desires can be mutually converted into each other as conditions change.

Williams realizes that individual deliberation can easily be reduced to wishful thinking. In this case, I know $\mathrm{P}$ is not true, but I have a strong desire for the state of affairs that $\mathrm{P}$ manifests. I in the end believe $\mathrm{P}$ motivated by my desire, which is self-deception. This fact shows that thinking about what one individual should do, which is individual deliberation, usefully involves more than one person: we can think about what I should do. In this way, "we can help to sustain each other's sense of reality, both in stopping wishes' becoming beliefs when they should not, and also in helping some wishes rather others to become desires." [13] Williams installs a social dimension into the construction of beliefs, attitudes and desires. "These are the materials of idiosyncrasy, and the lesson is that we need each other in order to be 
anybody." Unlike Rousseau conducting self-discovery in solitude, Williams presents us a scene in which we need each other to construct and stabilize our beliefs and desires, thus social cooperation would be possible.

\section{Action Responsibility and Others}

In the second section, I point out that integrity includes self-identified categorical desires and ground projects. To show one's desires and projects, he has to do something. There is truth that integrity has to do with the relation between a person and his action [14]. One brings integrity about that he genuinely cares for something and act in the spirit of that.

As to the relation between an agent and his actions, his attitude shapes his action. "The point is that he is identified with his actions as flowing from projects and attitudes which in some cases he takes seriously at the deepest level." [15] Simply put, the agent's decision and action should be acknowledged by himself or he would be alienated from his own projects and actions. Williams takes an example to illustrate this alienation. Jim, opposed to killing, happens upon a scene of execution in a small town in South America. Twenty Indians, randomly selected from the inhabitants of a rebellious village, are about to be killed to warn other possible protestors. The captain in charge of this mission offers Jim a privilege of killing one of the Indians himself. If Jim does, then the rest of Indians will be released. If not, twenty Indians will all be executed. Other villagers beg Jim to accept the captain's request. What should Jim do?

In Williams' opinion, according to utilitarianism, Jim should kill the Indian to save the rest, which is in contradiction with his life credo. When the action conducted is not acknowledged by his attitudes, with psychological effect on the agent considered, he may feel bad, thinking that he has done the wrong thing. His subsequent conduct and relations are crippled. What's more, such psychological effect cannot be seen as irrational or be ruled out, as utilitarianism does - they are after all one man's feelings, compared to the maximum outcomes. "Because our moral relation to the world is partly given by such feelings, and by a sense of what we can or cannot live with." [16] To regard those feelings from a purely utilitarian point of view is to alienate one from one's moral feelings, thus the sense of moral identity is lost, and integrity as well. The main point here is that the agent should act in accordance with his own attitudes, beliefs and inclination. If not, integrity may be deprived.

Williams puts too much weight so far on an agent inward attitudes and feelings that shape his actions. One more step forward, solipsism will arise. However, in action aspect, others are necessary to help construct the agents' self. It is true that the agent's attitude shapes his action. The action that the agent conducts, conversely, shapes himself too. Before illustrating this point, Williams' criticism on Kant's idea of responsibility should be examined.

Kant supposes that good will has categorical value. "A good will is not good because of what it effects or accomplishes, because of its fitness to attain some proposed end, but only because of its volition, that is, it is good in itself." [17] Whatever the outcome is, good will would shine by itself like a jewel, as something that has its full worth in itself. The reason why good will is so important in moral value is that its moral worth stems from human's free will. In doing so, Kant locates the agent's action responsibility totally in voluntariness. Thus, an agent's action is divided into voluntary and non-voluntary part, consequently, the agent is split into voluntary and non-voluntary self. Williams denies this point for that "there are two sides to action, that of deliberation and that of result, and there is a necessary gap between them." [18] An agent may deliberate and act as well as he can, but it turns out quite the opposite way. But the agent is a unified individual, the self is closely related to one's actions. There is no such self in which sense the self is detached from the state of affairs, because the self is defined not only through one's voluntariness, but also through one's actions, whether intentional or unintentional [19]. The distinction between what one has done and what one has not done has special significance, "that can be as important as the distinction between the voluntary and the non-voluntary." [20]

Williams, instead, endorses ancient Greek ethical thoughts. By analyzing Homer's Epic, he summarizes four basic elements of the conception of responsibility, namely: cause, intention, state, and response. Cause means that someone has brought about a bad state of affairs in virtue of what he did; intention means that he did or did not intend that state of affairs; state means that he was or was not in a normal state of mind when he brought it about; and response means that it is his business, if anyone's, to make up for it. All the conceptions of responsibility are constructed by interpreting these four elements in different ways and varying the emphasis between them. "There is not, and there never could be, just one appropriate way of adjusting these elements to one another - as we might put it, just one correct conception of responsibility." [21] There are many ways of relating them. In different contexts, different elements are emphasized. In Williams' view, it is an illusion that the conception of responsibility confines response entirely to the voluntary.

Among these elements, cause is primary for that the other issues can arise only in relation to the fact that some agent is the cause of what has come about. Without it, there is no conception of responsibility. In this sense, what I have done is an important fact in ethical life. It is no less important than what I have voluntarily done. "In most spheres of our life regulated by ideas of responsibility, the governing rule relates response to cause: the aim is that the response should be applied to a person whose action was the cause of the harm." [22] Those who have been hurt need a response. They have a right to seek it. This kind of responses is demanded by some other people. This is about one's action effects on others and attitude to others' lives. Apart from that, there is a question of one's attitude to oneself. Accordingly, there is another aspect of responsibility that comes from the demand of oneself. Because of Oedipus' grave sin of killing his father and marrying his mother, disasters such plague and famine keep 
befalling Thebe. When Oedipus finds out the truth, he cannot forgive himself and stab his eyes to blind. He, however, is still loved and respected by the residents in the polis. The residents pity him for what he has gone through. The pity is aroused not just by what he later suffered, "but by what he did, and by his own acknowledgement of what he did: how he sees what he did and how others see it form, as they must in any such case, a pair whose parts structure each other." [23] A person's self-cognition is related to how others see him. Williams regards the agent as a unified self so that the agent as a whole becomes the bearer of action responsibility. In this way to understand action responsibility, it takes a dynamic perspective instead of a static one to treat the agent's actions and their effects in helping construct self-cognition [19]. The main point here is that we would reflect on ourselves due to the effects, especially unintentional terrible effects, that our action brings about. During the reflection, the presence of others helps us construct self-cognition.

\section{Conclusion}

As it has been discussed so far, others play an essential role in Williams' integrity theory. We need others to help us sustain the sense of reality and to desire something realistic. Some scholars criticize Williams' integrity theory as too subjective by using the slavery example [24]. The example means that a person in favor of slavery wants to be a slave owner to retain his self-conception. As far as I'm concerned, this example is not an appropriate one as objection for that the person's desire in this example is not based on the reality that slavery is not morally justifiable nowadays. The person's desire is just wishful thinking in terms of Williams' terms. We need others' response to ascribe our action responsibility, contrary to Kantian moral responsibility which is confined totally to the voluntary action; we need others to help us acquire, and stabilize self-cognition and self-conception, and form steady attitudes, beliefs and motivations in order to better cooperate with others. Thus, the relationship between one's projects and himself is not just mediated all by himself. If a person forms wishful thinking, he should change that with the help of others. If a person brings about terrible effect with his project, he should not continue doing the same thing.

Williams never questions the value of morality. He agrees that morality is necessary and everyone should be moral, at least not be self-centered. $\mathrm{He}$, at most, questions the philosophical way of talking about morality, as utilitarianism and Kantian ethics do, which pursuits universality and systematization. In doing so, the problems of moral life, especially the moral conflicts or tragedy, is much more simplified. Though Williams does not make clear about the relationship between non-moral considerations and moral ones, he offers us insightful views on the limits of philosophy and the acquisition of morality.

There is no straight road to people's acquisition of morality, not to mention moral philosophy. "Moral philosophy cannot deliver the very thing that might been expected of it, a theory to guide ethical reasoning. What it can do is to assist the self-understanding of those whose ethical reasoning already has guidance from elsewhere. That is, it can help to provide a critique of lived ethical experience." [25] If the process of socialization goes well, we acquire morality during that process. If a person becomes idiosyncratically uncooperative and self-centered because of the impact of social world, "there are no reasonings drawn from this process that can rationally require him to be something else. What they may be able to do is to give us ideas of how to make him into something else, and perhaps to discourage others from being like him, to the extent - and this is a real question - that we really want to discourage everyone from being like him." [26]

We can say that Williams explains the existence of moral solipsist in terms of internal reasons. This doesn't mean he would agree on the proposal that moral solipsist shouldn't change a thing. Neither does it mean that Williams' theory of integrity represents solipsism. To some extent, we should distinguish explanatory from normative. Facing a moral solipsist, Williams, at most, may say that there may hardly be a way to change him. Philosophical arguments can only provide an idea how to do that while maybe there is no motivation for the solipsist to change, because such arguments may not relate to his $S$ to convince him. To put him in society and let him interact with others and internalize the value of morality may make up for the limits of philosophy.

\section{Acknowledgements}

I would like to thank the postgraduate Research and Innovation Program of Jiangsu Province for supporting me. My project name is The Research on Williams' Theory of Integrity, and the project number is KYCX20-1202. I also would like to thank my mentor and classmates to help me. All of these enable me to complete this article better.

\section{References}

[1] Williams, Bernard, Moral Luck, Cambridge: Cambridge University Press, 1982, pp. 10-11.

[2] Williams, Bernard, Moral Luck, Cambridge: Cambridge University Press, 1982, pp. 105.

[3] Xiangdong, Xu, Self, Others and Morality-An Introduction to Moral Philosophy, Beijing: The Commercial Press, 2007, pp. 653.

[4] Huijuan, Sun, Integrity, Moral Incapacity and Categorical Desires, Lanzhou Academic Journal, (5), 2014.

[5] Taylor, Charles, The Ethics of Authenticity, Cambridge: Harvard University Press, 1991, pp. 28.

[6] Varga, Somogy and Charles Guignon, Authenticity, The Stanford Encyclopedia of Philosophy (Spring 2020 Edition), Edward N. Zalta (ed.), URL $<$ https://plato.stanford.edu/archives/spr2020/entries/authenticit $\mathrm{y} />$.

[7] Williams, Bernard, Truth and Truthfulness, Princeton: Princeton University Press, 2002, pp. 184. 
[8] Donghua, Wang, Internal Reasons and Reason Solipsism-Criticism on Williams' Internalism, Morality and Civilization, (1), 2019.

[9] Williams, Bernard, Truth and Truthfulness, Princeton: Princeton University Press, 2002, pp. 194.

[10] Williams, Bernard, Truth and Truthfulness, Princeton: Princeton University Press, 2002, pp. 72.

[11] Williams, Bernard, Truth and Truthfulness, Princeton: Princeton University Press, 2002, pp. 74.

[12] Williams, Bernard, Truth and Truthfulness, Princeton: Princeton University Press, 2002, pp. 192.

[13] Williams, Bernard, Truth and Truthfulness, Princeton: Princeton University Press, 2002, pp. 198.

[14] Taylor, Gabriele and Raimond Gaita, Integrity, Proceedings of the Aristotelian Society, Supplementary Volumes, Vol. 55, 1981.

[15] Smart, J. J. C. and Bernard Williams, Utilitarianism: For and Against, Cambridge: Cambridge University Press, 1973, pp. 116.

[16] Smart, J. J. C. and Bernard Williams, Utilitarianism: For and Against, Cambridge: Cambridge University Press, 1973, pp. 103.
[17] Kant, Immanuel, Groundwork of the Metaphysics of Morals, trans., Gregor, Mary, Cambridge: Cambridge University Press, 1998, p. 46

[18] Williams, Bernard, Shame and Necessity, Berkeley: University of California Press, 1993, pp. 69.

[19] Huijuan, Sun, Bernard Williams' Criticism on Kantian Moral Responsibility, Morality and Civilization, (2), 2019.

[20] Williams, Bernard, Ethics and the Limits of Philosophy, London: Routledge, 2006, pp. 177.

[21] Williams, Bernard, Shame and Necessity, Berkeley: University of California Press, 1993, pp. 55.

[22] Williams, Bernard, Shame and Necessity, Berkeley: University of California Press, 1993, pp. 57.

[23] Williams, Bernard, Shame and Necessity, Berkeley: University of California Press, 1993, pp. 71.

[24] Ashford, Elizabeth, Utilitarianism, Integrity and Partiality, The Journal of Philosophy, Vol. 97, No. 8, 2000, pp. 421-439.

[25] Williams, Bernard, Ethics and the Limits of Philosophy, London: Routledge, 2006, pp. 202.

[26] Williams, Bernard, Truth and Truthfulness, Princeton: Princeton University Press, 2002, pp. 200. 